\title{
Cellulolytic activity and structure of symbiotic bacteria in locust guts
}

\author{
L.-J. Su*, H. Liu*, Y. Li, H.-F. Zhang, M. Chen, X.-H. Gao, F.-Q. Wang \\ and A.-D. Song \\ College of Life Sciences, Henan Agricultural University, Zhengzhou, Henan, \\ China \\ *These authors contributed equally to this study. \\ Corresponding author: A.-D. Song \\ E-mail: song1666@126.com
}

Genet. Mol. Res. 13 (3): 7926-7936 (2014)

Received August 9, 2013

Accepted November 18, 2013

Published September 29, 2014

DOI http://dx.doi.org/10.4238/2014.September.29.6

ABSTRACT. Locusts are able to digest the cellulose of Gramineae
plants, resulting in their being considered as major crop pests.
To illustrate the mechanism involved in cellulose digestion, the
cellulolytic activity and zymography in the gut contents of 16 locust
species were determined using carboxymethyl cellulose (CMC) as
substrate. The diversity of gut symbiotic bacteria was studied using
denaturing gradient gel electrophoresis (DGGE). The results showed
that high CMC activity was present in Acrididae gut fluid (mean
356.4 U/g proteins). Of the 5 locust species, Oxya chinensis had
the highest diversity of intestinal symbiotic bacteria, characterized
by the DGGE profile containing more than 20 bands of $16 \mathrm{~S}$ rRNA.
Klebsiella pneumoniae, in the gut of Locusta migratoria manilensis,
was identified as the most abundant symbiotic bacterium by DNA
sequencing, with a relative abundance of $19.74 \%$. In comparison,
Methylobacterium sp was the most dominant species in the
Atractomorpha sinensis gut, with a relative abundance of $29.04 \%$.
The results indicated that the cellulolytic enzymes and gut microbial 
communities probably reflected their phylogenetic relationship with different locust species and associated feeding strategies.

Key words: Carboxymethyl cellulose; Cellulolytic zymography; Denaturing gradient gel electrophoresis; Locust; Symbiotic bacteria

\section{INTRODUCTION}

In the natural environment, some insect groups, such as termites (all 7 families) and xylophagous beetles (Blattidae, Cryptocercidae, Anobiidae, Buprestidae, Cerambycidae, and Scarabaeidae), are able to utilize lignocellulosic materials efficiently. The specific intestinal structures of these species are regarded as highly efficient natural biological reactors. These insects live in trees, dead branches, and fallen leaves, and use lignocellulosic plants as their only source of food. Moreover, they have the ability to degrade and transform lignocellulose; thus, they are regarded as arthropods that are important in the natural carbon cycle (Sun and Michael, 2010). For many years, much research effort has been focused on termites and beetles, due to the high level of destruction that they cause to trees. In contrast, research into the mechanisms of how locusts biodegrade Gramineae plants, which are important food sources, has been neglected.

Locusts (Orthoptera: Acridoidea) have chewing mouthparts, and feed on Gramineae grasses with cellulose contents of as much as $30-50 \%$. Due to the major disasters caused by locusts, research on this group has mainly focused on prevention and control, biological characteristics, and species classification. Thus, cellulose digestion by locusts has been rarely studied. Oppert et al. (2010) compared the cellulase activity of 8 orders of insects, and found that Orthoptera insects exhibited high intestinal cellulase activity that is similar to that of Coleoptera insects. Willis et al. (2010) isolated and purified a type of cellulase from Dissosteira carolina. One bacterial strain that is able to degrade cellulose has been isolated from locust guts (Wang et al., 2010b). These studies indicate that the ability of locusts to digest cellulose efficiently is similar to that of termites and beetles.

In this study, we determined the cellulase activity and cellulolytic zymography of 16 locust species collected from the wild using carboxymethyl cellulose (CMC) as the substrate. In addition, to determine the diversity of microbes in the locust gut, the intestinal symbiotic bacteria of 5 common locust species found in Henan Province, China, were investigated by denaturing gradient gel electrophoresis (DGGE) method. The results obtained by this study are anticipated to provide a theoretical basis illustrating the mechanism of cellulose digestion by locusts.

\section{MATERIAL AND METHODS}

\section{Locust collection and dissection}

The taxonomy (family, genus, and species names) of adult locusts, along with the number of specimens and collection sites used in the experiments, are listed in Table 1. The insects were collected from May to September 2012. The insects were collected from the field (at least 3 individuals of each species), and were starved for $24 \mathrm{~h}$ to empty any food residue 
from the gut. Individuals were cooled to $4^{\circ} \mathrm{C}$ before dissection to the slow metabolism and provide easier handling. After the insect intestines were dissected on ice, the dissected tissues were cut into small pieces, homogenized with liquid nitrogen, dissolved in high purity water at $100 \mathrm{mg}$ tissues $/ \mathrm{mL}$, vortex-mixed, and centrifuged at $16,000 \mathrm{~g}$ for $5 \mathrm{~min}$ at $4^{\circ} \mathrm{C}$. Supernatants were used as crude cellulase samples, transferred to new centrifuge tubes, and stored at $-80^{\circ} \mathrm{C}$ until use.

Table 1. Taxonomy, number, and collection locality of the locusts used in the experiments.

\begin{tabular}{|c|c|c|c|c|}
\hline Number & Family & Genus species & Tested replicates & Collection locality \\
\hline 1 & Acrididae & Gonista bicolor & 3 & ZYW \\
\hline 2 & & Phlaeoba sinensis & 3 & NEW \\
\hline 3 & & Mongolotettix japonicus & 3 & DSM \\
\hline 4 & & Chrysacris sinucarinata & 10 & ZYW \\
\hline 5 & & Acrida cinerea & 3 & LWD \\
\hline 6 & Arcypteridae & Pararcyptera microptera meridionalis & 3 & ZYW \\
\hline 7 & & Arcyptera fusca fusca & 3 & DSM \\
\hline 8 & Oedipodidae & Parapleurus alliaceus & 3 & LWD \\
\hline 9 & & Epacromius coerulipes & 3 & ZYW \\
\hline 10 & & Locusta migratoria manilensis & 3 & ZYW \\
\hline 11 & & Gastrimargus marmoratus & 5 & YDM \\
\hline 12 & Catantopidae & Fruhstorferiola viridifemorata & 3 & ZYW \\
\hline 13 & & Oxya chinensis & 5 & ZYW \\
\hline 14 & & Hieroglyphus annulicornus & 3 & ZYW \\
\hline 15 & Pyrgomorphidae & Atractomorpha sinensis & 5 & ZYW \\
\hline 16 & & Atractomorpha lata & 3 & DSM \\
\hline
\end{tabular}

ZYW = Zhengzhou Yellow River wetland; NEW $=$ Nanzhao eighteen waterfall; DSM = Dengfeng Songshan mountain; LWD = Lushan white dragon pool; YDM = Yuzhou City Dahongzhai mountain.

\section{Determination of cellulolytic activity}

The protein content of the gut samples was quantitatively determined using the Coomassie protein assay (Pierce, USA), with bovine serum albumin as the standard (Bradford, 1976). Cellulolytic activity was determined using CMC (Sigma, USA) as the substrate. The specific determination steps used were: $0.2 \mu \mathrm{L}$ crude enzyme solution (protein content 10$50 \mu \mathrm{g})$ was added to $1.8 \mathrm{~mL} 1 \%$ CMC-Na solution ( $1 \mathrm{~g} \mathrm{CMC}-\mathrm{Na}$ to $100 \mathrm{~mL}$ acetate buffer, $\mathrm{pH}$ 4.8). The resulting solution was held in a water bath at $55^{\circ} \mathrm{C}$ for $1 \mathrm{~h}$. After this, $2 \mathrm{~mL}$ 3,5-dinitrosalicylic acid was added, and the solution was boiled for $10 \mathrm{~min}$ to deactivate the enzyme liquid. The color was allowed to develop, and a constant volume of $1.5 \mathrm{~mL}$ was set. Then, the sugar concentration was reduced using spectrophotometer with a wavelength of $550 \mathrm{~nm}$. The inactivated enzyme solution was used as a comparison. The definition used for enzyme activity under the stated conditions is the amount of enzyme required to produce $1 \mu \mathrm{mol}$ glucose/min. The enzyme activity unit is IU/mg (Oppert et al., 2010). All specific activity was represented by the averages of at least 3 independently pooled samples (i.e., biological replicates).

\section{Cellulolytic zymography}

In this study, zymograms to detect cellulolytic activity bands were performed as described previously (Picart et al., 2007), with minor modifications. Specifically, 0.1\% CMC 
was added to $10 \%$ SDS-PAGE. Gel mixtures were heated to $30^{\circ} \mathrm{C}$, while $\mathrm{CMC}$ was added slowly to prevent aggregation. Then, after the CMC had dissolved, APS and TEMED were added. The resultant solution was left to polymerize overnight at room temperature. The prepared sample was partially denatured at $70^{\circ} \mathrm{C}$ for $10 \mathrm{~min}$, to reduce the dispersion of the cellulolytic activity bands. Then, after centrifuging, it was loaded with the protein. The sample quantity was 3-4 $\mu \mathrm{g}$ for each electrophoresis lane. Electrophoresis was processed at $100 \mathrm{~V}$ and $4^{\circ} \mathrm{C}$ for approximately $4 \mathrm{~h}$, or until the dye reached the bottom of the gel. The acquired bands were washed sequentially with $2.5 \%(\mathrm{w} / \mathrm{v})$ Triton $\mathrm{X}-100$ for $1 \mathrm{~h}$ and $50 \mathrm{mM}$ acetic acid buffer, $\mathrm{pH} \mathrm{5}$, for $1 \mathrm{~h}$. Afterwards, samples were placed in a warm bath at $55^{\circ} \mathrm{C}$ for $30 \mathrm{~min}$ in the same buffer solution as described in the previous section. The bands were washed with $0.1 \%(\mathrm{w} / \mathrm{v})$ Congo red for $15 \mathrm{~min}$, until the plates were clear. Then, a photograph was taken and processed using the Adobe Photoshop CS2 software.

\section{Extraction of gut contents and microorganism total DNA}

Five locusts from each species were selected. The insects were starved in advance for $24 \mathrm{~h}$, to empty food residues from the gut. The locusts were dissected in an ice bath. The guts were placed into $1.5-\mathrm{mL}$ sterilized centrifuge tubes containing $1 \mathrm{~mL}$ Tris-EDTA (including $1 \%$ crosslinked polyvinylpyrrolidone) buffer. Then, the guts were scarified and repeatedly washed, and the intestinal wall tissue was discarded. Finally, the gut contents were obtained. The gut contents were centrifuged at $5000 \mathrm{~g}$ for $5 \mathrm{~min}$, and the supernatant was collected. Then, genomic DNA was extracted using a Soil DNA kit (OMEGA, USA).

\section{S rRNA V3 section amplification}

The primers used in this experiment were F341-GC (5'-CGC CCG CCG CGC GCG GGC GGG GCG GGG GCA CGG GGG GCC TAC GGG AGG CAG CAG-3') and R518 (5'ATT ACC GCG GCT GCT GG-3'). The reaction condition used (for touch down PCR) was: the samples were pre-denatured at $95^{\circ} \mathrm{C}$ for $3 \mathrm{~min} ; 95^{\circ} \mathrm{C}$ for $30 \mathrm{~s}, 65^{\circ} \mathrm{C}$ (reducing the temperature gradually by $0.5^{\circ} \mathrm{C}$ for each cycle) for $30 \mathrm{~s}, 72^{\circ} \mathrm{C}$ for $30 \mathrm{~s}$, and circulating 20 times under 3 conditions. Then, further treatment was given at $95^{\circ} \mathrm{C}$ for $30 \mathrm{~s}, 53^{\circ} \mathrm{C}$ for $30 \mathrm{~s}, 72^{\circ} \mathrm{C}$ for $30 \mathrm{~s}$, circulated 15 times, with a final extension at $72^{\circ} \mathrm{C}$ for $7 \mathrm{~min}$. Afterwards, the sample was tested on agarose gel with a mass fraction of $1 \%$, and the PCR amplification products were preserved at $-20^{\circ} \mathrm{C}$ until use.

\section{DGGE analysis}

Samples containing $45 \mu \mathrm{L}$ of the PCR products from the 16S rRNA V3 section amplification were mixed with $5 \mu \mathrm{L}$ loading buffer 6 times. In the DGGE Bio-Rad gel electrophoresis, $8 \%$ polyacrylamide gel and a denaturant concentration of $30-60 \%$ (100\% denaturant containing $7 \mathrm{mM}$ urea and $40 \%$ deionized formamide) were used. Electrophoresis was performed at $200 \mathrm{~V}$ for $10 \mathrm{~min}$. After this, the sample was rapidly run out of the lane, and electrophoresis was then processed at $120 \mathrm{~V}$ and $60^{\circ} \mathrm{C}$ for $6 \mathrm{~h}$. After electrophoresis, the DGGE profile was obtained by SYBR ${ }^{\circledR}$ Green (Invitrogen, USA) staining.

For the DGGE analysis, the DGGE images were processed using the Quantity one 
4.62 software (Bio-Rad, USA). The quantity values (Q values) corresponding to each output band were divided by the sum of all the recovered $Q$ values. Subsequently, the relative abundance was obtained.

\section{DGGE band tapping sequencing}

In the references on the DGGE profile, the main bands were cut under UV light and then placed in sterilized $1.5-\mathrm{mL}$ centrifuge tubes for DNA recovery. Then, using the recovered DNA as a template, and F341 (5'-CCT ACG GGA GGC AGC AG-3') and R518 as primers, PCR amplification was performed. The PCR resultant products were sent to the Shanghai Sangon Biotech Company in China for sequencing. Finally, homology comparisons among the sequencing results and the nucleic acid data in the NCBI GenBank database were made and analyzed.

\section{RESULTS}

\section{Cellulolytic activity of locust species}

The cellulolytic activity of 16 locust species using CMC as the substrate is shown in Figure 1. The figure shows that the CMC activity of the samples ranged from 164.9 to 398.6 $\mathrm{U} / \mathrm{g}$ protein. Of these samples, Acrididae had the highest CMC activity, with an average protein activity of $356.4 \mathrm{U} / \mathrm{g}$. Gonista bicolor had the highest CMC activity (number 1 in Figure 1), which reached $398.6 \mathrm{U} / \mathrm{g}$ protein. In contrast, Atractomorpha lata had the lowest CMC activity, with only $169.4 \mathrm{U} / \mathrm{g}$ proteins (number 16 in Figure 1). Arcypteridae and Oedipodidae followed Acrididae, and had average activities of 331.2 and $305.0 \mathrm{U} / \mathrm{g}$ protein, respectively. Finally, Catantopidae and Pyrgomorphidae had the lowest CMC activity, with 210.9 and 171.0 $\mathrm{U} / \mathrm{g}$ protein, respectively.

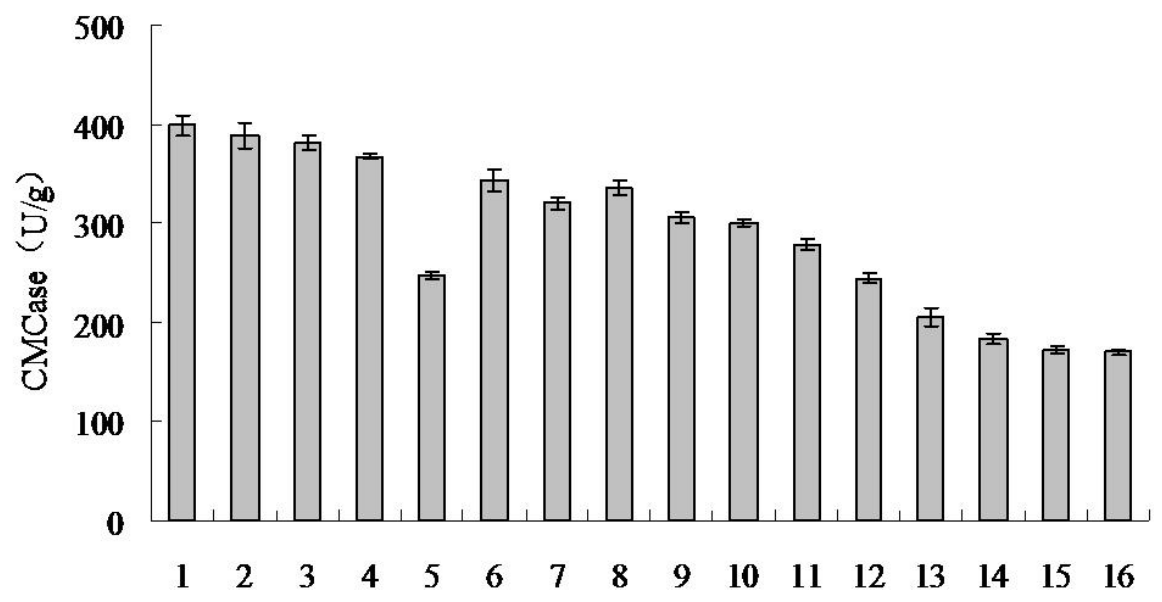

Figure 1. Cellulolytic activities (U/g protein) of gut fluid from a diverse range of locusts using CMC as substrate. The numbers on the $\mathrm{x}$-axis correspond to the data in Table $1(1-5=$ Acrididae; 6 and $7=$ Arcypteridae; $8-11=$ Oedipodidae; 12-14 = Catantopidae; 15 and 16 = Pyrgomorphidae). 


\section{Cellulolytic zymography analysis}

The cellulolytic zymograms are shown in Figure 2. Different locust species (represented by the activity band numbers) exhibited different CMC activity. Most of the locusts had 3-4 cellulose zymography bands, with a single species having a maximum of 5 bands. The molecular weight of the zymographs lay in a range of around $16-160 \mathrm{kD}$.

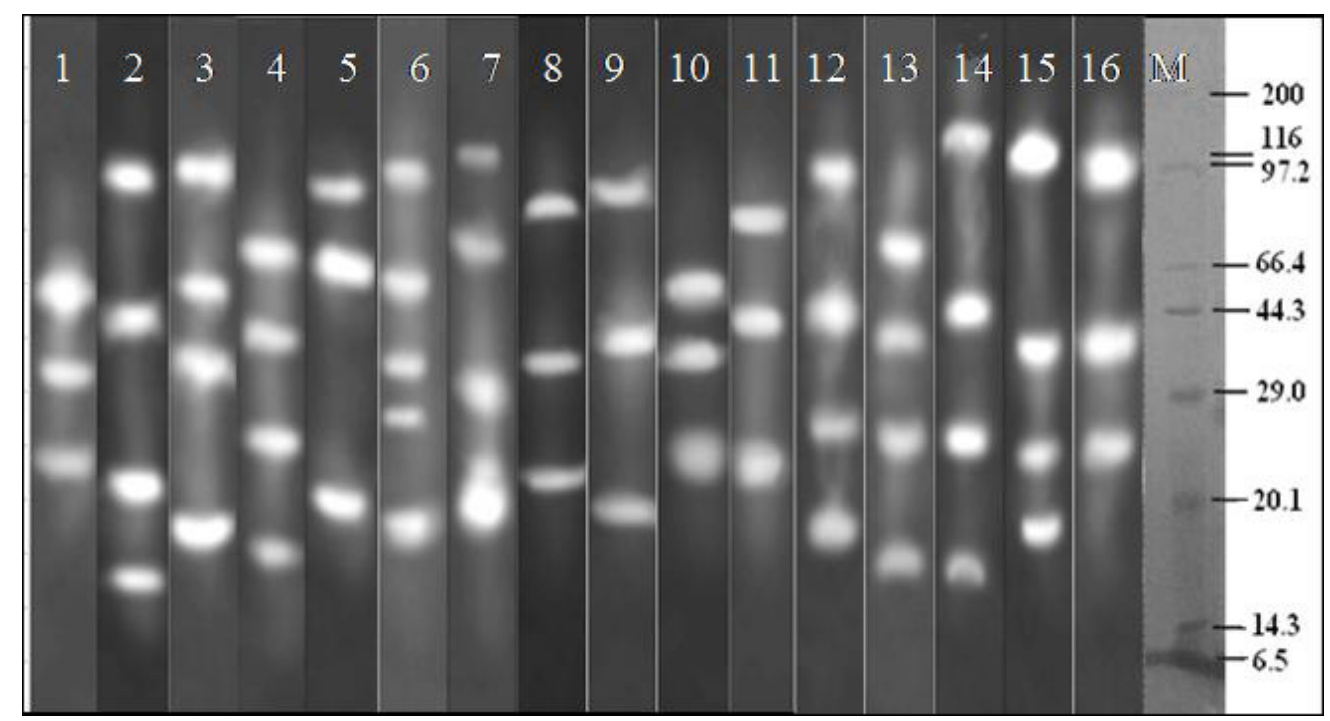

Figure 2. Cellulolytic zymography in gut fluid from diverse locust species. The numbers in white correspond to Table 1. Lane $M=$ a protein marker (kDa).

\section{Total DNA extraction and PCR amplification}

The intestinal bacteria extracted from 5 locust species (Atractomorpha sinensis, Acrida cinerea, Locusta migratoria manilensis, Gastrimargus marmoratus, and Oxya chinensis) produced genomic DNA fragments with sizes of around $20 \mathrm{~kb}$, which was consistent with the bacterial genomic DNA fragments. In addition, the fragment sizes obtained from the PCR amplification in the bacteria V3 section of the 5 locust species was around $200 \mathrm{bp}$.

\section{DGGE profile analysis}

DGGE profiles of the 5 locust species are shown in Figure 3. Five lanes contained bands that clearly had different numbers and intensities. This result indicated that there were significant differences in the diversity and abundance of intestinal symbiotic bacteria extracted from different locust species. As shown in Figure 3, O. chinensis (lane e) had the richest symbiotic bacteria community, with about 20 types of microorganisms. This species was followed by A. sinensis (lane a), L. migratoria manilensis (lane c), and A. cinerea (lane b), with about 14,13 , and 11 types of bacteria, respectively. The species with the lowest variety of symbiotic bacteria was $G$. marmoratus (lane d), with only about 5 types of bacteria. 


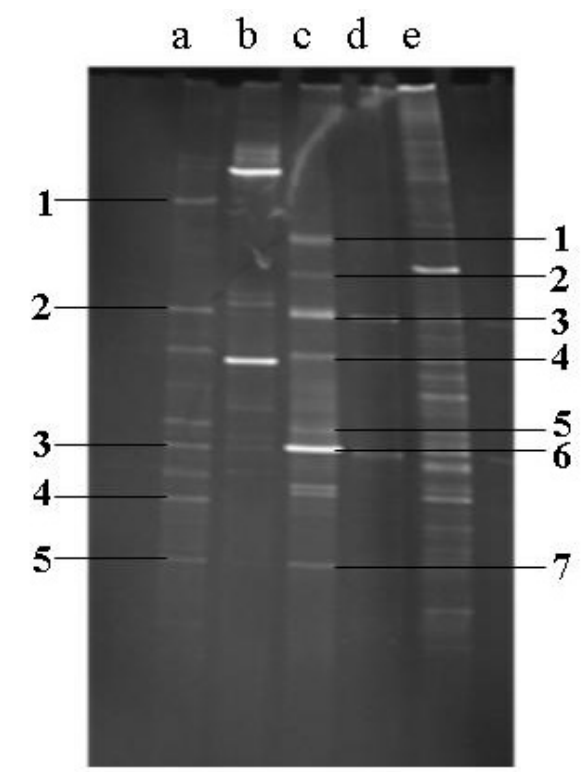

Figure 3. DGGE profile of locust gut symbiont. a. Atractomorpha sinensis; b. Acrida cinerea; c. Locusta migratoria manilensis; d. Gastrimargus marmoratus; e. Oxya chinensis. The numbers in the bands correspond to Tables 3 (band a) or 4 (band c).

\section{DGGE band recovery sequencing}

The DGGE band sequencing results showed that the intestinal symbiotic bacteria of $L$. migratoria manilensis were consistent with 7 different phylotypes (Table 2). These phylotypes included Klebsiella sp, Pseudomonas aeruginosa, Bacillus sp, Arthrobacter sp, and Staphylococcus xylosus. Among these bacteria, Klebsiella pneumoniae was the most dominant group, with a relative abundance of $19.74 \%$. This species was followed by Bacillus thuringiensis and S. xylosus. P. aeruginosa and Klebsiella oxytoca had the lowest relative abundance, of 11.61 and $10.90 \%$, respectively.

The intestinal symbiotic bacteria of $A$. sinensis had 5 types of phylotypes (Table 3 ). These phylotypes included Methylobacterium, Bacillus, Actinomycete, Treponema, and Streptococcus. Here, Actinomycete was the most dominant group, with a relative abundance of $21.95 \%$, while Streptococcus was the least abundant group, with a relative abundance of just $15.48 \%$.

Table 2. BLAST sequencing analysis of Locusta migratoria manilensis gut symbiont V3 section.

\begin{tabular}{llrr}
\hline Number & Most similar strain in GenBank (accession No.) & Identities (\%) & Relative abundance (\%) \\
\hline 1 & Staphylococcus xylosus (JX661717.2) & 100 & 14.64 \\
2 & Arthrobacter ardleyensis (AJ551163.2) & 99 & 12.03 \\
3 & Bacillus thuringiensis (HE610860.1) & 99 & 17.17 \\
4 & Bacillus alkalitelluris strain DT29-2 (JF411277.1) & 13.91 \\
5 & Pseudomonas aeruginosa strain KBS0806 (JQ797655.1) & 11.61 \\
6 & Klebsiella pneumoniae (JN848787.1) & 99 & 19.74 \\
7 & Klebsiella oxytoca (HE610790.1) & 99 & 10.90 \\
\hline
\end{tabular}

The numbers correspond to the bands shown in Figure 3 of lane $\mathrm{c}$. 
Table 3. BLAST sequencing analysis of Atractomorpha sinensis gut symbiont V3 section.

\begin{tabular}{llcc}
\hline Number & Most similar strain in GenBank (accession No.) & Identities (\%) & Relative abundance (\%) \\
\hline 1 & Uncultured Methylobacterium sp clone 14fr (FN651843.2) & 99 & 21.04 \\
2 & Uncultured Bacillus sp clone AS_MJ_49 (JQ615566.1) & 100 & 21.72 \\
3 & Uncultured Actinomycete clone ch-xj15 (JQ327962.1) & 100 & 21.95 \\
4 & Uncultured Treponema sp clone CRgS120(JN703759.1) & 99 & 19.81 \\
5 & Streptococcus oralis strain HV 0s122 (JQ782211.1) & 99 & 15.48 \\
\hline
\end{tabular}

The numbers correspond to the bands shown in Figure 3 of lane a.

\section{DISCUSSION}

\section{Comparison of cellulolytic activity among locusts, termites, and beetles}

Insect-cellulose research has mainly focused on Isoptera (termites) and Coleoptera (beetles). For example, 3 bark beetle species (Dendroctonus armandi, Polygraphus sinensis, Ips acuminatu) found in the Qinling Mountains, China, that fed on the trunk phloem and xylem of healthy $>30$-year-old Pinus armandii have been extensively studied. The CMC activity of this species is $458-729 \mathrm{U} / \mathrm{g}$ protein. The symbiotic bacteria of this insect were able to secrete cellulase, hemicellulase, amylase, and protease, among other substances. Thereby, the cellulose, hemicellulose, starch, polysaccharide, lipid, protein, and other nutrients in the phloem and xylem of host $P$. armandii could be utilized (Wang and Chen, 2008). The intestinal cellulolytic activity of Oncideres albomarginata chamela was reported to be $208.13 \mathrm{U} / \mathrm{g}$ protein (Calderón-Cortés et al., 2010), while the intestinal cellulolytic activity of Reticulitermes hageni was reported to be $523 \mathrm{U} / \mathrm{g}$ protein (Oppert et al., 2010).

Willis et al. (2010) extracted cellulases from the foregut and hindgut of D. carolina. These cellulases were highly similar to the $\beta$-1,4-endopeptidase in invertebrates, fungi, and bacteria, while no homologues were identified for the gut-derived protein. The present study also found that Orthoptera locusts had high cellulolytic activity, ranging from 105.2 to 398.6 $\mathrm{U} / \mathrm{g}$ protein. The CMC activity and cellulose digestion capability of locusts appears to be as high as those recorded for termites and beetles in previous publications. Thus, locusts could use the cellulose of gramineous plants as their energy source.

\section{Comparison of cellulolytic activity among different locust species}

Locusts have chewing mouthparts, in addition to pairs of large and efficiently toothed mandibles. Thus, they are able to chew plant stems and leaves easily, and feed on gramineous plants. This group of animals is highly capable of digesting cellulose, with this ability being closely linked to the composition of their gut the digestive enzymes that it contains. For example, Arcypteridae preferentially feed on tough Gramineae-like Bambusoideae plants with higher cellulose content. Wang et al. (2010a) found that the structure of locust maxillary teeth has close relationship with the type of host plant. For instance, Oedipoda miniata and O. coerulescens, which belong to the Oedipodidae family, have molar teeth with the morphological characteristics adapted for cutting and grinding. Thus, these locusts would be able to digest Gramineae and Cyperaceae plants that have higher cellulose content, in addition to being able to digest Cruciferae and Boraginaceae plants that have lower cellulose content. In comparison, 
Alliptamus italicus, belonging to the Catantopidae family, has cutting teeth, which are suitable for crushing and chewing soft plant leaves with lower cellulose content; however, this species would have difficulty digesting tough leaves that need grinding.

The present study found that the CMC activity of locusts was ordered (from highest to lowest): Acrididae $>$ Arcypteridae $>$ Oedipodidae $>$ Catantopidae $>$ Pyrgomorphidae. Based on the different teeth types and plants fed on by the locusts, our results confirmed that Arcypteridae locusts primarily feed on Gramineae plants with high cellulose content (Wang et al., 2010a), and are expected to mainly used cellulose and plant starch as their main sources of energy. Catantopidae locusts mainly feed on Gramineae plants with low cellulose content. Oedipodidae locusts are able to digest plants with both high and low cellulose content (Wang et al., 2010a); Hence the CMC activity of this type of locust falls between that of Arcypteridae and Catantopidae locusts.

\section{Functional analysis of symbiotic microbes in locust guts}

There were obvious differences in the intestinal bacteria community of different locust species. Zhao et al. (2008) cultured 8 bacterial strains after purifying and isolating intestinal bacteria from L. migratoria manilensis raised under laboratory conditions. Among these bacteria strains, Klebsiella sp and Enterobacter cloacae were dominant in the resident bacteria community. In comparison, the dominant intestinal bacterial communities of Schistocerca gregaria, which fed on the leaves and stems of plants, were Enterobacter and Streptococcus. Zeng et al. (2007) screened 4 strains of bacteria with high cellulolytic activity from the gut of Gomphocerus sibiricus. These strains were preliminarily identified as Corynebacterium xerosis, Staphylococcus auricularis, and 2 unknown strains.

The 5 species of locust collected in the present study also exhibited noticeable differences in the diversity and abundance of the intestinal bacterium community. The diversity of intestinal bacterium communities in these 5 locust species were ordered (from highest to lowest): $O$. chinensis $>$ A. sinensis $>$ L. migratoria manilensis $>$ A. cinerea $>$ G. marmoratus. The results indicate that the different feeding habits of the locusts regulate the types of bacterial species in the gut, based on the varying ability of locusts to digest cellulose. This relationship led to significant variation in the dominant intestinal bacterium community. Based on our results, it was assumed that $O$. chinensis was better able to utilize cellulose compared to $G$. marmoratus, while G. marmoratus was able to generate more endogenous cellulases.

This study showed that the intestinal bacteria community of $L$. migratoria manilensis mainly includes K. pneumoniae, B. thuringiensis, S. xylosus, Bacillus alkalitelluris, Arthrobacter ardleyensis, $P$. aeruginosa, and $K$. oxytoca. The intestinal bacterial community of $A$. sinensis contained high levels of Actinomycetes, Bacillus, Methylobacterium, Treponema, and Streptococcus oralis. The majority of these resident intestinal bacteria were able to degrade cellulose. This statement supports a previous study by Tao et al. (2011) who extracted Arthrobacter flavescens from ocean floor sediments and solid cultured medium of edible fungi. $A$. flavescens was found to have high cellulolytic activity, as well as strong antagonistic activity against Penicillium, Trichoderma, and Rhizopus. In another study, Dröge et al. (2006, 2008) isolated new Treponema isoptericolens and Spirochaeta coccoides from the hindgut of termites (Incisitermes tabogae). The 2 bacteria exhibited the correct enzyme activity for the degradation of lignocellulose, as they contained enzymes such as $\beta$-D-glucosidase, $\alpha$-L-arabinosidase, and $\beta$-xylosidase. Wilson (1992) reported the cloning and expression of cellulase genes from 
multiple Actinomycetes. Furthermore, the authors studied the regulation mechanism for the secretion of these genes. Watanabe et al. (2003) isolated 4 different Actinomycetes from the guts of 2 termite species (Coptotermes formosanus and Reticulitermes speratus) using different culture media. Two Actinomycetes grew well on the culture medium containing lignocellulose (e.g., CMC, dealkaline lignin) as the sole carbon source. In comparison, the other 2 Actinomycetes only developed well on cellulose-based culture media. Various studies have demonstrated that Bacillus is not able to induce cellulase by using cellulose as the only carbon source, but must first be induced by monosaccharides and disaccharides containing reducing groups. Moreover, the synthesis expression of each cellulase component occurs on synergy (Yan and Yang, 2006). Therefore, it is speculated that for cellulose to be digested in locust guts, it must be degraded by endogenous cellulase and cellulase produced by gut microbiome. S. xylosus used xylose, galactose, and other components of hemicelluloses for cellulose digestion. On the other hand, Bacillus is able to synthetize small amounts of enzymes, which are able to degrade hemicellulose or other substances into xylose, galactose, mannose, and other substances. These products break into the cells, and induce Bacillus to produce cellulase. Thus, intestinal cellulolytic activity and comprehensive cellulose digestive ability in locust guts is improved through mutual cooperation.

In summary, locusts primarily fed on gramineous plants and were able to digest cellulose. The locusts exhibited high intestinal cellulolytic activity and contained diverse types of microorganisms that were able to secrete cellulase. However, questions remain, such as: 1) how many types of cellulase are there; 2) the location of cellulase in the gut of locusts; and 3) does cellulose digestion mainly depend on endogenous digestive enzymes or intestinal symbiotic bacteria? These issues require further investigation to ultimately elucidate the mechanism of locust cellulose digestion. The results obtained in this study provide a theoretical basis for the rational design and construction of natural, efficient, and stable bionic systems for lignocellulose degradation.

\section{ACKNOWLEDGMENTS} (\#31170350).

\section{REFERENCES}

Bradford MM (1976). A rapid and sensitive method for the quantitation of microgram quantities of protein utilizing the principle of protein-dye binding. Anal. Biochem. 72: 248-254.

Calderón-Cortés N, Watanabe H, Cano-Camacho H, Zavala-Páramo G, et al. (2010). cDNA cloning, homology modelling and evolutionary insights into novel endogenous cellulases of the borer beetle Oncideres albomarginata chamela (Cerambycidae). Insect Mol. Biol. 19: 323-336.

Dröge S, Fröhlich J, Radek R and König H (2006). Spirochaeta coccoides sp. nov., a novel coccoid spirochete from the hindgut of the termite Neotermes castaneus. Appl. Environ. Microbiol. 72: 392-397.

Dröge S, Rachel R, Radek R and König H (2008). Treponema isoptericolens sp. nov., a novel spirochaete from the hindgut of the termite Incisitermes tabogae. Int. J. Syst. Evol. Microbiol. 58: 1079-1083.

Oppert C, Klingeman WE, Willis JD, Oppert B, et al. (2010). Prospecting for cellulolytic activity in insect digestive fluids. Comp. Biochem. Physiol. B Biochem. Mol. Biol. 155: 145-154.

Picart P, Diaz P and Pastor FI (2007). Cellulases from two Penicillium sp. strains isolated from subtropical forest soil: production and characterization. Lett. Appl. Microbiol. 45: 108-113.

Sun JZ and Michael ES (2010). Exploring and integrating cellulolytic systems of insects to advance biofuel technology. 
Insect Sci. 17: 163-165.

Tao JG, Lu WD, Xu LL and Guo LZ (2011). Characterization of the antagonistic strains used for culturing of edible fungi and optimization of their fermentation conditions. J. Qingdao Agric. Univ. 28: 50-54.

Wang H, Yu F, Chen RH, Wang ZY, et al. (2010a). Mandible difference of seven dominant grasshopper species in Xinjiang grasslands. Chin. Bull. Entomol. 47: 759-762.

Wang JH, Xiong Z, Wang F, Wang XJ, et al. (2010b). Isolation of cellulase producing strains in alimentary canal of Yunnanacris yunnaneus. Hubei Agric. Sci. 49: 874-878.

Wang SJ and Chen H (2008). Digestion enzymes of three bark beetle species (Ooleoptera: Scolytidae) in the Qingl ing Mountains. J. Northwest A\&F Univ. 36: 142-148.

Watanabe Y, Shinzato N and Fukatsu T (2003). Isolation of actinomycetes from termites' guts. Biosci. Biotechnol. Biochem. 67: 1797-1801.

Willis JD, Klingeman WE, Oppert C, Oppert B, et al. (2010). Characterization of cellulolytic activity from digestive fluids of Dissosteira carolina (Orthoptera: Acrididae). Comp. Biochem. Physiol. B Biochem. Mol. Biol. 157: 267-272.

Wilson DB (1992). Biochemistry and genetics of actinomycete cellulases. Crit. Rev. Biotechnol. 12: 45-63.

Yan H and Yang Q (2006). Study on induction mechanism of cellulase production by two bacilli. Chem. Ind. Forest Prod. 26: $77-80$.

Zeng XC, Ji R and Mou GP (2007). Screen of high-yield cellulase strain from intestinal of Gomphocerus sibiricus. Food Sci. 28: 388-392.

Zhao Y, Zhang ZH and Wang GJ (2008). Identification of the intestinal bacteria in Locusta migratoria manilensis and their antagonism to Metarhizium anisopliae. Plant Protection 34: 69-72. 